\title{
Environmental Literacy among Prospective Classroom Teachers in Jordan
}

\author{
Eman Gheith \\ University of Petra \\ Amman, Jordan
}

\begin{abstract}
This study aims to determine the level of environmental literacy among Prospective teachers by considering its three aspects (knowledge, attitudes, and behavior), the relation between these aspects, and the impact of the academic year level on environmental literacy. It also intends to explore the sources that students draw on to develop environmental literacy. The study sample consists of 112 female students enrolled at the University of Petra, Amman, Jordan, in the Department of Education Science. A questionnaire was created by the researcher to collect data composed of five parts and a total of 62 items to measure environmental literacy and to identify the sources that students depend on to obtain environmental Literacy. The results of the study showed that prospective teachers had positive attitudes toward the environment as the percentile grade was $77 \%$. However, environmental knowledge was lower than the acceptable level as the percentile performance on the test reached 50.7\%; also the level of environmental behavior was less than the acceptable level as it reached $65 \%$. The results also showed that there are statistically significant differences in environmental attitudes among prospective teachers according to their academic level which was favorable to 4th-year students. The study also showed that there was a positive and significant correlation reached (0.437) between students' environmental attitudes and their behavior.
\end{abstract}

Keywords: environmental literacy; environmental knowledge; environmental attitudes; prospective classroom teacher; environmental behaviour.

\section{Introduction}

Recently, environmental issues have become equally significant among both developed and developing societies. This attention has grown with the increase of environmental problems such as global warming, ozone depletion, pollution and unsustainable use of water resources, all of which have created serious problems that cannot be ignored in the relation between human beings and their environment. Consequently, people have had to study any activity or behavior 
that can endanger their shared environment. In dealing with the environment there are two groups: one group is responsible for destroying the environment for the sake of economic growth while the other group defends the environment and supports its challenges by employing reliable scientific data (Khalaf, 2012). Many countries are aware of the environmental problems that endanger human life and limit economic growth, both in the short and long term. This has resulted in realizing the importance of protecting and maintaining the environment while managing environmental problems. Because the main reason for environmental problems is due to careless human activity, solving this situation requires finding solutions and requires increasing the number of people who possess a reasonable degree of environmental awareness (AtabekYiğit, Köklükaya, Melike and Demirhan, 2014).

Environmental education has emerged as a modern educational approach in the 1970s to date. For the past four decades, there has been an agreement about the importance of environmental education in achieving sustainable societies (Dada, Eames, and Calder, 2017). On the one hand, many developed and developing countries realize that managing and solving environmental problems requires adopting appropriate environmental policies and, on the other hand, providing members of the society of all ages with suitable opportunities to become more environmentally aware and more committed to work for the environment in such a way that they can participate in finding solutions to environmental problems and protecting natural resources (Erdoğan, Kostova, and Marcinkowski, 2009; Saribas, and Akdemi, 2019). In order to develop individual awareness and positive attitudes toward the environment, it is necessary that educational institutions, whether schools or universities, stress environmental literacy among students or through informal educational means such as religious institutions, environmental organizations, and various media (Erdoğan, 2009).

Teachers play a vital role in helping students achieve goals of environmental education as well as in preparing environmentally literate students. However, if a teacher lacks sufficient knowledge, attitude, and skills in the field of environment, it is difficult for him/her to prepare environmentally literate students. Therefore, it is necessary to pay attention to developing the level of environmental literacy among pre-service teachers and to improving their competence so they can create and execute effective environmental activities in the classroom when they become professional teachers (Dada, Eames, and Calder, 2017; Cheng and So, 2015; Kaya, and Elster, 2018; Arikand and Yilmaz, 2017).

Attention to the environment on the global level started in the early 1970s through various organizations such as UNESCO, the International Union of the Environment, and the UN program for Environment Affairs. The Stockholm Conference in 1972 was one of the most important events that shaped the actual initiation of global environmental thinking and the beginning of group awareness of the necessity to protect the environment and maintain it. The Conference recommended the necessity of recognizing the importance of environmental education. As a result, many NGOs were established and 
supported to maintain the environment (UNEP, 1972; O'Neill, 2007). The role of environmental education was promoted to solve environmental problems and develop literacy in every international conference after that, especially the Belgrade Conference in 1975, in which the goals of environmental education were established, and the Tbilisi Conference in 1977 (Gillett, 1977). The latter conference puts forward principles and guidelines for environmental education and literacy.

The term literacy appeared at the end of the 18th century and was used then to refer to the ability to read and write. However, after the Industrial Revolution, the term had a larger application. During the past fifty years, the term has been used to refer to the individual's ability to understand and take appropriate decisions that concern problems facing society. The term has been further expanded to refer to knowledge in various areas such as scientific literacy, computer literacy, and environmental literacy (MacBride et al., 2013).

Roth (1992) indicates that environmental literacy is based on ecological consciousness which is primarily the ability to understand and explain the ecosystem and take appropriate decisions to protect it. He adds that environmental literacy is the result of three factors. The first is knowledge, which refers to ecological concepts and human impact on the ecosystem and knowledge of environmental issues and working strategies. The second is the affective aspect which is concerned with individual attitudes, personal responsibility, and environmental values. Finally, there is behavior that can be shown through the individual's specific environmental activities. Environmental knowledge, skills, and attitudes are important predictors of environmental behavior; however, they are not sufficient.

Morrone, Mancl, and Carr, (2001) indicate that environmental literacy is a relatively recent concept, and the definition of environmental literacy is not unanimously agreed upon by researchers. The characteristics of an environmentally literate individual were a controversial issue and a subject of discussion until the beginning of the current century. Most of the studies dealing with environmental literacy at the end of the 20th century investigated the extent of an individual's knowledge regarding pollution but ignored important aspects such as environmental sensitivity, personal beliefs, making decisions, and solving problems. Environmentally literate individuals should be able to relate their knowledge to values that lead them to work for the environment. Thus, environmental literacy constitutes more than knowledge as it includes values, attitudes, skills, and behavior (Dermanand, and Hacieminoğlu, 2017).

Disinger (2001) indicates that discussions about the concept of environmental literacy led to clarifying the definition by determining the important factors needed for an individual to be considered environmentally literate, and by clarifying the relationship between environmental literacy and education. Coyle, (2005) indicates that environmental education comprises a series of steps that lead to a total dynamic understanding of the topic and includes developing skills and learning how to apply them in real-life situations. The first step is increasing environmental awareness among individuals by providing them with simple knowledge of environmental topics, the second step is to promote 
personal conduct, which is a combination of awareness and behavior that encourages individuals to develop personal attitudes, the third step includes knowledge and acting on behalf of the environment, which requires individuals to have a deep knowledge of and willingness to work for the environment (thinking and acting).

Malandrakis, Boyesand, and Stanisstreet, (2011) concluded that high school students have a low tendency to practice pro-environmental behavior despite their belief in the importance of these practices. Fielding and Head, (2012) indicate that individuals between the ages of 18-24 are less concerned with the environment and less willing to participate in environmental activities compared to those who are older. Therefore, it is necessary to include principles of environmental education in teacher programs and provide prospective teacher with an acceptable level of environmental literacy as this will determine what they will pass on to their students (Öztürk, Tüzün, and Teksöz, 2013).

Many studies that investigated the relationship between environmental education and environmental literacy show low levels of environmental knowledge and awareness among students (Weber, Hair, and Fowler, 2000). A study conducted in America by Coyle (2005) indicates that individuals obtained environmental knowledge from various sources such as school, media, family and friends, activities outside the home, and personal work experience. However, this knowledge is unrelated, faulty, and insufficient, regardless of age, gender, or income. As for the relationship between environmental knowledge and attitudes, studies have arrived at different conclusions: some showed that there is a positive relation (Arcury, 1990) while others showed a negative relation or the absence of a significant statistical relation (DeChano, 2006).

\section{Previous research}

Many studies have been conducted with regard to environmental literacy among pre-service and in-service teachers both on a local and global level. The following is a review of the main studies.

\section{Local studies}

Al-Khalwaldeh (2000) conducted a study that aimed at assessing the level of environmental literacy among science teachers in Jordan. The results of the study showed that the level of environmental literacy was intermediate. Also, Batayneh's research (2012) measured the level of environmental literacy among environmental institution leaders and Jordanian university students with regard to sustainable development. Results indicated that leaders of environmental institutions showed a high level of environmental literacy while the level among university students was intermediate. Moreover, Al-Dajeh (2012) evaluated the level of environmental literacy among pre-service teachers in the areas of knowledge, attitudes, and interests. The results showed that the sample possessed insufficient knowledge of environmental issues. On the other hand, their attitude was positive and they displayed a high level of interest in 
environmental matters. The main source of information regarding the environment was the Internet.

In 2013 Al-Omari and Al-Khawaldeh carried out a study that aimed at determining the level of environmental literacy among educational science students at Yarmouk University, Jordan. The results indicated that the level of environmental knowledge and attitudes was lower than acceptable level (75\%), but that environmental practices and interest in such matters were at an acceptable level. Ayash and Abu Snaneh (2013) attempted to determine the effect of a training program to develop environmental literacy and positive attitudes toward the environment among female students in the educational science department, UNWRA Faculty of Educational Sciences and Arts, in Jordan. Members of the sample were divided into two groups, experimental and control. A training program on environmental education was applied to the experimental group. Results showed statistical differences in averages among the two groups in favor of the experimental group.

\section{International research}

O'Brien (2007) was concerned with the level of environmental knowledge and attitudes among students at Iowa State University (ISU). Results showed that the students had a medium level of environmental literacy and that there was a relation between the students' environmental knowledge, attitudes, and demographic characteristics such as age, gender, college, academic year, and childhood environment and activities. Also, Özden (2008) conducted a study to assess environmental awareness and attitudes among pre-service teachers in Turkey. Results showed that female students who came from a high socioeconomic background had more environmental awareness and their attitudes toward the environment were more positive.

The research of Tuncer et al., (2009) was concerned with the level of environmental literacy among pre-service teachers at one of the largest government universities in Turkey. Research was conducted to find a relation between the level of environmental literacy, attitudes, interest in environmental problems, being active in open-air environmental activities, as well as interest in parents' environmental activities. Results showed that environmental knowledge among pre-service teachers was positively related to environmental literacy and attitudes. In addition, research undertaken by Öztürk, Tüzün, and Teksöz (2013) examined the level of environmental literacy among pre-service teachers in various specializations in Turkey and studied the effect of certain factors such as gender, academic specialization, and level. The results indicated that there was an effect related to gender, academic year level, and specialization on aspects of environmental literacy.

Joseph, Obrin Nichol, Janggu, and Madi, (2013) proposed to test the level of environmental literacy among business administration instructors at Malaysian universities. Results showed that the level of environmental literacy was slightly higher than average at 3.22/5. Moreover, Karatekin (2103) investigated the level of environmental literacy among pre-service teachers specializing in classroom teacher, social studies, and geography. The results acquired through a 
descriptive survey showed that the level of environmental literacy was high among teachers specializing in geography compared to other specializations. Also, Liu et al., (2015) conducted a study to determine the level of environmental literacy among teachers in Taiwan schools and to evaluate the effect of the environmental education policy enacted in 2011. The results showed that students displayed an acceptable level of environmental literacy and attitudes, but had low levels of participation in environmental activities. They also indicated that teachers in primary schools performed better than high school teachers due to their involvement in teacher preparation programs.

A recent study was done by Saribas, Kucuk, and Ertpinar, (2017) in Turkey attempted to discover the effects of environmental education courses on the environmental literacy level of elementary school student teachers. The students were exposed to the main ideas of ecology, climate change, and other environmental issues. The researchers used an environmental literacy and selfmotivation measure before and after the experiment. The results revealed an increase in their environmental attitudes, but no changes in their knowledge and interests. Also, Lloyd-Strovas, Moseley and Arsuffi (2018) conducted research to measure the level of environmental literacy as (everyday knowledge, actual knowledge, attitudes, and behavior) among BA/BS university students. The results showed the general average test scores were only $52 \%$, which indicates that the students were not environmentally literate. Though they showed positive attitudes, their scores were low in the areas of environmental knowledge and behavior.

From previous studies, the following can be concluded:

1. The results of the previous studies did not consistently agree with regard to the level of environmental literacy among prospective teachers in areas of knowledge, attitudes, and behavior. Some studies indicated that environmental literacy levels were medium (O'Brien, 2007, Al-Khawaldeh, 2000 ) or less than acceptable in the knowledge area (Al-Omari and AlKhawaldeh, 2013; Al-Dajeh, 2012; Lloyd-Strovas, Moseley and Arsuffi, 2018). Other studies showed positive attitudes toward the environment (Dajeh, 2012; Lloyd-Strovas, Moseley and Arsuffi, 2018), while still others indicated that environmental practices were below the acceptable level (Liu et al., 2016).

2. Some studies showed that there is a relationship between environmental literacy and teacher's characteristic with regard to age, gender, and socioeconomic level as well as specialization and previous knowledge or between environmental literacy and taking university courses in environmental education (O'Brien, 2007; Karatekin, 2013).

3. Most of the studies depended on an environmental literacy questionnaire for collecting data related to knowledge, attitudes, awareness, and behavior. 


\section{Problem of the study}

Protecting and maintaining the environment is an important issue that should be given attention by developed and developing countries so they can face the challenges of increasing environmental problems. Any actions that nations take regarding the protection of the environment must start with people, as they are the main cause of environmental problems. Only human beings can find suitable solutions for these problems or mitigate their harsh effects. Therefore, there is a compelling need to explore the level of environmental literacy among the most important group in society, namely, pre-service classroom teachers who will work on teaching students in the first three grades. This research will indicate the extent of environmental literacy, the relationship between the various aspects of environmental literacy, the impact of environmental education in preparing teachers in Jordanian universities, and the ability of these programs to equip pre-service teachers with suitable environmental skills so they can elevate the standard of environmental literacy among students when they become teachers. Consequently, this study is an attempt to answer the following questions:

1. What is the level of environmental literacy among prospective teachers at the University of Petra?

2. What is the relationship between the aspects of environmental literacy, namely, environmental knowledge, attitudes, and pro-environmental behavior?

3. What is the effect of the level of the academic year on the degree of environmental literacy among pre-service teachers?

4. What are the main sources students rely on to obtain environmental knowledge?

\section{Importance of the research}

The significance of this study stems from its dealing with environmental literacy, a vital concern for developed and developing countries. This research will reveal the level of environmental literacy among prospective teachers as well as show the relation between aspects of environmental literacy and academic year. This is especially relevant since many studies have determined that the level of environmental literacy will influence their teaching practices. Consequently, the research will contribute to improving environmental literacy among students. Finally, this research will highlight the effectiveness of teachers preparing programs in environmental education at Jordanian universities.

\section{Procedural definitions}

Environmental literacy: knowledge about environmental issues and problems locally and globally as well as values and positive attitudes toward studying the environment and interacting with it, which in turn contributes to shaping environmentally friendly behavior (Lloyd-Strovas, Moseley, and Arsuffi, 2018); Al-Omari and Al-Khawaldeh, 2013) 
Adequacy limits: the minimum acceptable degree of environmental literacy is $70 \%$ of the total for each of the environmental literacy dimensions because several previous studies considered scores between $70-75 \%$ as an indicator of acceptable level of environmental literacy (Al-Dajeh, 2012; Jasim, 2001; Liu et al., 2015).

\section{Study limitations}

The limits of this study are as the following:

1. This study was limited to a sample of female students from the Department of Educational Sciences, specializing in a classroom teacher at the University of Petra because the Ministry of Higher Education in Jordan does not allow male students to enroll in the classroom teacher program.

2. The dimensions of the environmental literacy scale included three parts, namely, knowledge, attitudes, and behavior.

3. The minimum acceptable level of environmental literacy is $70 \%$ because several previous studies considered scores $70 \%$ as an indicator of an acceptable level of environmental literacy.

\section{Methods and Procedures}

Study methodology: this study adopted the descriptive survey method

\section{Study population and Sample}

The population of the study was all students registered in the University of Petra for the second semester academic year 2018-2019 in the Education Science Department /Classroom Teacher. The sample of the study included 112 students from the University of Petra who were selected randomly. The study sample was distributed over the academic years as follows: 22 students in the first year, 47 students in the second year, 32 third years, and 11 fourth years.

\section{Tools of the study}

A questionnaire was used to collect data on the level of environmental literacy in three areas: knowledge, attitudes, and behavior. The questionnaire was built by the researcher after reviewing several related studies such as (Özden, 2008; AlDajeh, 2012; O’Brien, 2007; Erdoğan, 2009).

The final form of the questionnaire included several parts. Part 1 contained information about the participants' academic level; Part 2 is composed of 22 items to measure environmental attitudes. Each item had five answers on the Likert Scale (5-strongly agree, 4-agree, 3-not sure, 2- don't agree, 1-strongly disagree). The scores on this scale ranged from 22-110 with an average from 1-5. Part 3 is composed of an 18 question multiple-choice test. Each question has 4 answers, one of which is correct. This is to measure the students' knowledge of environmental topics, local and global environmental issues. The student is given one score for each correct answer and zero for each wrong one. The score ranged between $0-18$ and a percentage between $0-100$. Part 4 is a questionnaire 
with 21 items involved with how much student practices environmentally friendly acts. Each item has 4 answers on the Likert Scale (4-always, 3-often, 2sometimes, 1-never). The scores ranged from 21-84 with an average from 1-4. Part 5 has one question to indicate sources the student draws on to obtain environmental knowledge; the student is asked to choose three sources out of nine possibilities.

The preliminary questionnaire had 22 environmental knowledge questions, 30 questions regarding attitudes, and 21 questions related to environmental behavior. It was given to faculty members from the University of Petra, whose comments were taken into consideration. Some parts were deleted and others modified. The final questionnaire had 18 multiple choice questions on environmental knowledge, 22 items to measure environmental attitudes, 21 items in the area of environmental behavior and one question to indicate sources to obtain environmental knowledge.

The reliability of the study scale was calculated using Chronbach's alpha test, where the reliability coefficient on the attitude scale reached $(0.68)$, on environmental behavior scale reached (0.85), and on environmental knowledge test reached (0.81).

\section{Results of the study}

The normality test for the sample scores on the environmental literacy scale (knowledge, attitudes, and behaviors) was applied. Table 1 shows the results of the test.

Table 1: Tests of Normality

\begin{tabular}{|l|r|c|r|r|r|r|}
\hline \multirow{2}{*}{$\begin{array}{l}\text { Environmental } \\
\text { literacy scale }\end{array}$} & \multicolumn{3}{|c|}{ Kolmogorov-Smirnov } & \multicolumn{3}{c|}{ Shapiro-Wilk } \\
\cline { 2 - 7 } & Statistic & \multicolumn{1}{c|}{ df } & \multicolumn{1}{c|}{ Sig. } & \multicolumn{1}{c|}{ Statistic } & \multicolumn{1}{c|}{ df } & \multicolumn{1}{c|}{ Sig. } \\
\hline Attitudes & .095 & 112 & .014 & .988 & 112 & .403 \\
Knowledge & .103 & 112 & .005 & .980 & 112 & .090 \\
behaviors & .066 & 112 & $.200^{*}$ & .988 & 112 & .419 \\
\hline
\end{tabular}

From the table above, using the Shapiro-Wilk test, we observe that all statistically significant values are greater than $(\alpha=0.05)$, this shows that the data is normally distributed.

To answer the first question, which is concerned with the level of environmental literacy among pre-service teachers, calculations were made of means, standard deviations, and percentages of frequencies on the scale of environmental literacy which constituted three dimensions: knowledge, attitudes, and behaviors. Table 2 shows results that are related to the environmental attitudes of participants 
Table 2: Means, standard deviations, and frequencies for the items on the scale of environmental attitudes scale

\begin{tabular}{|c|c|c|c|c|c|c|c|c|}
\hline & Item & $\begin{array}{l}\text { Strongly } \\
\text { agree } \\
\%\end{array}$ & $\begin{array}{c}\text { Agree } \\
\%\end{array}$ & $\begin{array}{l}\text { Not } \\
\text { sure } \\
\%\end{array}$ & $\begin{array}{c}\text { Disagree } \\
\%\end{array}$ & $\begin{array}{l}\text { Strongly } \\
\text { disagree } \\
\%\end{array}$ & mean & \begin{tabular}{|c} 
St. \\
Dev.
\end{tabular} \\
\hline 1 & $\begin{array}{l}\text { I can participate in improving } \\
\text { the environment through } \\
\text { personal behavior }\end{array}$ & 42.9 & \begin{tabular}{|l|}
48.2 \\
\end{tabular} & 8.9 & 0 & 0 & 4.34 & 0.64 \\
\hline 2 & $\begin{array}{l}\text { We can reduce the destruction } \\
\text { of the environment by } \\
\text { applying laws and regulations }\end{array}$ & 56.3 & 42.0 & 1.8 & 0 & 0 & \begin{tabular}{|l|l|}
4.54 \\
\end{tabular} & 0.54 \\
\hline 3 & $\begin{array}{l}\text { Acquiring more knowledge } \\
\text { will help me to protect the } \\
\text { environment in my daily } \\
\text { activities }\end{array}$ & 51.8 & \begin{tabular}{|l|}
45.5 \\
\end{tabular} & 2.7 & 0 & 0 & \begin{tabular}{|l|l|}
4.49 \\
\end{tabular} & 0.55 \\
\hline 4 & $\begin{array}{l}\text { Protecting the environment is } \\
\text { the responsibility of each } \\
\text { individual }\end{array}$ & 80.4 & \begin{tabular}{|l|}
15.2 \\
\end{tabular} & 3.6 & 0.9 & 0 & 4.75 & 0.56 \\
\hline 5 & $\begin{array}{l}\text { I can influence my colleagues, } \\
\text { family, and friends regarding } \\
\text { environmental issues }\end{array}$ & 13.4 & \begin{tabular}{|l|}
33.9 \\
\end{tabular} & 22.3 & 24.1 & 6.3 & 3.24 & 1.15 \\
\hline 6 & $\begin{array}{l}\text { Impose fines on factory } \\
\text { owners who cause pollution } \\
\text { and reward those who use } \\
\text { environmentally friendly } \\
\text { materials }\end{array}$ & 62.5 & 25.0 & 8.0 & 0.9 & 3.6 & 4.42 & 0.95 \\
\hline 7 & $\begin{array}{l}\text { The need to start teaching } \\
\text { environmental topics to } \\
\text { students at a young age }\end{array}$ & 58.9 & 34.8 & 6.3 & 0 & 0 & 4.53 & 0.61 \\
\hline 8 & $\begin{array}{l}\text { Initiating laws and enforcing } \\
\text { penalties prevents } \\
\text { environmental instability }\end{array}$ & 10.7 & 29.5 & 19.6 & 26.8 & 13.4 & 2.97 & 1.24 \\
\hline 9 & $\begin{array}{l}\text { Despite controversies among } \\
\text { scientists regarding climate } \\
\text { change, it is necessary to enact } \\
\text { suitable procedures to protect } \\
\text { the environment }\end{array}$ & 14.3 & 33.0 & 27.7 & 18.8 & 6.3 & 3.3 & 1.12 \\
\hline 10 & $\begin{array}{l}\text { People have the right to exploit } \\
\text { natural resources in order to } \\
\text { live in luxury }\end{array}$ & 9.8 & \begin{tabular}{|l|}
18.8 \\
\end{tabular} & 21.4 & 28.6 & 21.4 & 2.67 & 1.28 \\
\hline 11 & $\begin{array}{l}\text { Individual participation to } \\
\text { protect the environment is } \\
\text { necessary even if governments } \\
\text { are not concerned }\end{array}$ & 18.8 & \begin{tabular}{|l|l|}
27.7 \\
\end{tabular} & 14.3 & 16.1 & 23.2 & 3.03 & 1.46 \\
\hline 12 & $\begin{array}{l}\text { The importance of organizing } \\
\text { school field trips to visit } \\
\text { conservation areas }\end{array}$ & 55.4 & \begin{tabular}{|l|l|}
43.8 \\
\end{tabular} & 0.9 & 0 & 0 & \begin{tabular}{|l|}
4.54 \\
\end{tabular} & 0.52 \\
\hline 13 & $\begin{array}{l}\text { Individuals who damage the } \\
\text { environment must be } \\
\text { penalized }\end{array}$ & 63.4 & \begin{tabular}{|l|l|}
29.5 \\
\end{tabular} & 4.5 & 0.9 & 1.8 & \begin{tabular}{|l|}
4.52 \\
\end{tabular} & 0.78 \\
\hline 14 & $\begin{array}{l}\text { All living things have the right } \\
\text { to live regardless of their } \\
\text { importance to humanity }\end{array}$ & 49.1 & \begin{tabular}{|l|}
27.7 \\
\end{tabular} & 17.9 & 4.5 & 0.9 & 4.2 & 0.95 \\
\hline
\end{tabular}




\begin{tabular}{|c|l|l|l|l|l|l|l|l|}
\hline 15 & $\begin{array}{l}\text { I believe that if I reduce water } \\
\text { or energy consumption, it } \\
\text { helps to protect the } \\
\text { environment }\end{array}$ & 9.8 & 33.0 & 22.3 & 26.8 & 8.0 & 3.1 & 1.15 \\
\hline 16 & $\begin{array}{l}\text { Factories must reduce } \\
\text { pollution even it leads to } \\
\text { increased prices }\end{array}$ & 19.6 & 28.6 & 30.4 & 15.2 & 6.3 & 3.4 & 1.13 \\
\hline 17 & $\begin{array}{l}\text { Governments must prioritize } \\
\text { environmental issues even if it } \\
\text { leads to unemployment and } \\
\text { economic slowdown }\end{array}$ & 13.4 & 31.3 & 31.3 & 21.4 & 2.7 & 3.31 & 1.04 \\
\hline 18 & $\begin{array}{l}\text { I prefer to vote for a person } \\
\text { who prioritizes environmental } \\
\text { issues }\end{array}$ & 28.6 & 47.3 & 23.2 & 0.9 & 0 & 4.04 & 0.75 \\
\hline 19 & $\begin{array}{l}\text { I'm willing to buy more } \\
\text { expensive goods or pay a } \\
\text { higher tax if that will help to } \\
\text { protect the environment }\end{array}$ & 9.8 & 31.3 & 36.6 & 16.1 & 6.3 & 3.22 & 1.04 \\
\hline 20 & $\begin{array}{l}\text { We should protect the } \\
\text { environment for our children } \\
\text { and grandchildren even if we } \\
\text { have to lower living standards }\end{array}$ & 23.2 & 58.0 & 14.3 & 2.7 & 1.8 & 3.98 & 0.81 \\
\hline 21 & $\begin{array}{l}\text { I am worried about climate } \\
\text { change even though its effects } \\
\text { are not immediately apparent }\end{array}$ & 25.0 & 39.3 & 18.8 & 13.4 & 3.6 & 3.69 & 1.1 \\
\hline 22 & $\begin{array}{l}\text { I enjoy watching programs } \\
\text { that are concerned with nature }\end{array}$ & 33.9 & 48.2 & 11.6 & 5.4 & 0.9 & 4.09 & 0.87 \\
\hline & 35.29 & 35.17 & $\mathbf{1 5 . 3 3}$ & $\mathbf{9 . 3 7}$ & $\mathbf{4 4 . 8}$ & $\mathbf{3 . 8 4}$ & $\mathbf{0 . 3 3}$ \\
\hline
\end{tabular}

Table 2 shows that the means with regard to environmental attitudes ranged from 2.67-4.75 out of 5 with percentages ranging from 53-95\%. The mean is $3.84 / 5$ with a percentage of $77 \%$. This indicates that students obtained a medium score that shows positive environmental attitudes. As for evaluating the answers on each part of the environmental attitude scale, the table shows, whether they agree, disagree, or are not sure, that the average on the Likert Scale of 13 items of the questionnaire ranged from $3.69-4.75 / 5$ with percentages from $74 \%-95 \%$. This means that a large percentage of the students strongly agreed or agreed to the scale items, some of these items were as follows: I believe in the importance of organizing school and university field trips; it's possible to decrease damage to the environment by enforcing laws and regulations; gaining more knowledge might help me to protect nature; protecting nature is the responsibility of each individual; it's important to penalize individuals who damage nature. It is also noticed that there are nine items in which the student averages were less than $3.5 / 5$ because a large number of the participants said they strongly disagreed or disagreed or were not sure in the following items: it is the right of humans to exploit nature in order to live luxuriously; I see that imposing laws and penalties prevents environmental instability; I see that individual activities to protect nature are important even if governments are not concerned; I am willing to buy 
more expensive products and pay higher taxes if that would help protect nature; I believe that promoting water and energy conservation will help protect nature; the government should prioritize all environmental issues even if it leads to economic decline or increased unemployment; I believe I can influence family and friends with regard to issues of protecting nature.

To identify the level of environmental knowledge among the pre-service teachers, means, standard deviation, and percentages were calculated according to test results by calculating the correct answers of the 18 items. If the answer is correct, one score is given and zero if incorrect. Table 3 shows the results.

Table 3: Means, standard deviations, and percentages of participants' scores on the environmental knowledge test

\begin{tabular}{|c|c|c|c|c|c|}
\hline Category & Number & Statement & Mean & $\begin{array}{l}\text { Percentage } \\
\%\end{array}$ & $\begin{array}{c}\text { St. } \\
\text { Dev. }\end{array}$ \\
\hline \multirow{7}{*}{$\begin{array}{l}\text { General } \\
\text { environmental } \\
\text { knowledge }\end{array}$} & 1 & $\begin{array}{l}\text { Most natural water is found in seas } \\
\text { and oceans }\end{array}$ & 0.39 & 39 & 0.49 \\
\hline & 2 & $\begin{array}{l}\text { Plant residue decompose quickly in } \\
\text { nature }\end{array}$ & 0.77 & 77 & 0.43 \\
\hline & 3 & The sun is the source of global energy & 0.83 & 83 & 0.38 \\
\hline & 4 & $\begin{array}{l}\text { Sustainable development can be } \\
\text { achieved through careful dealing with } \\
\text { natural resources }\end{array}$ & 0.51 & 51 & 0.50 \\
\hline & 5 & $\begin{array}{l}\text { Air pollution can be decreased by } \\
\text { reducing public transport fare }\end{array}$ & 0.29 & 29 & 0.46 \\
\hline & 6 & $\begin{array}{l}\text { The ozone layer protects living things } \\
\text { by absorbing ultraviolet radiation }\end{array}$ & 0.74 & 74 & 0.44 \\
\hline & Total & & 3.52 & 59 & 1.41 \\
\hline \multirow{7}{*}{$\begin{array}{l}\text { Knowledge of } \\
\text { local } \\
\text { environmental } \\
\text { issues }\end{array}$} & 7 & $\begin{array}{l}\text { The household area (kitchen, } \\
\text { bathroom, etc.) of maximum water } \\
\text { consumption in Jordan }\end{array}$ & 0.19 & 19 & 0.39 \\
\hline & 8 & $\begin{array}{l}\text { Most water consumption in Jordan is } \\
\text { in agriculture }\end{array}$ & 0.40 & 40 & 0.49 \\
\hline & 9 & $\begin{array}{l}\text { Most petroleum products are used in } \\
\text { various forms of transportation in } \\
\text { Jordan }\end{array}$ & 0.56 & 56 & 0.50 \\
\hline & 10 & $\begin{array}{l}\text { Most garbage decomposition occurs in } \\
\text { covered garbage dumps in Jordan }\end{array}$ & 0.48 & 48 & 0.50 \\
\hline & 11 & $\begin{array}{l}\text { The national flower in Jordan is the } \\
\text { black iris }\end{array}$ & 0.77 & 77 & 0.42 \\
\hline & 12 & $\begin{array}{l}\text { Jordan depends on underground } \\
\text { sources for its water }\end{array}$ & 0.47 & 47 & 0.50 \\
\hline & Total & & 2.87 & 48 & 1.28 \\
\hline \multirow{4}{*}{$\begin{array}{l}\text { Knowledge of } \\
\text { global } \\
\text { environmental } \\
\text { issues }\end{array}$} & 13 & $\begin{array}{l}\text { The best method to obtain energy is to } \\
\text { use solar and wind power to reduce } \\
\text { the greenhouse effect }\end{array}$ & 0.70 & 70 & 0.46 \\
\hline & 14 & $\begin{array}{l}\text { Chlorofluorocarbons causes ozone } \\
\text { depletion }\end{array}$ & 0.28 & 28 & 0.45 \\
\hline & 15 & $\begin{array}{l}\text { Ice melting and climate changes are } \\
\text { caused by global warming }\end{array}$ & 0.32 & 32 & 0.47 \\
\hline & 16 & Carbon dioxide is a major cause of & 0.54 & 54 & 0.50 \\
\hline
\end{tabular}




\begin{tabular}{|l|c|l|c|c|c|}
\hline & \multicolumn{1}{|l|}{ global warming } & & & \\
\cline { 2 - 6 } & 17 & $\begin{array}{l}\text { Tropical forests are exploited in } \\
\text { developing nations to earn income by } \\
\text { exporting wood }\end{array}$ & 0.32 & 32 & 0.47 \\
\cline { 2 - 6 } & 18 & $\begin{array}{l}\text { Greenhouse gases absorb infrared rays } \\
\text { and prevent them from leaving the } \\
\text { atmosphere }\end{array}$ & 0.47 & 47 & 0.50 \\
\cline { 2 - 6 } & Total & & 2.63 & $44 \%$ & 1.31 \\
\hline $\begin{array}{l}\text { Scale as a } \\
\text { whole }\end{array}$ & & 9.04 & 50.17 & 2.74 \\
\hline
\end{tabular}

Table 3 shows that the mean of the participants' scores reached 9.04 from 18, with a percentage value of $50.17 \%$. This means that the level of environmental knowledge is low.

Also, it's noticed from Table 3 that the percentage value of the participants' scores in the three areas of environmental knowledge is as follows: general environmental knowledge is $59 \%$, local is $48 \%$, and global is $44 \%$. This indicates that students don't have sufficient environmental knowledge in its three aspects, especially with regard to global environmental issues.

Also, student scores in the environmental knowledge test were divided into four categories. The number of students was calculated for each category as well as the percentage results. Table 4 shows these results.

Table 4: Dividing participants into categories according to their scores in the environmental knowledge test

\begin{tabular}{|l|c|c|c|c|c|}
\hline $\begin{array}{l}\text { Environmental } \\
\text { knowledge test } \\
\text { Score categories }\end{array}$ & $85-100 \%$ & $70-84 \%$ & $55-69 \%$ & $40-54 \%$ & $\begin{array}{c}\text { Less than } \\
40 \%\end{array}$ \\
\hline $\begin{array}{l}\text { Number of } \\
\text { students }\end{array}$ & & 10 & 38 & 33 & 31 \\
\hline $\begin{array}{l}\text { Percentage of } \\
\text { students }\end{array}$ & & $9 \%$ & $34 \%$ & $29 \%$ & $28 \%$ \\
\hline $\begin{array}{l}\text { Level of } \\
\text { knowledge }\end{array}$ & Sufficient & Sufficient & Insufficient & Insufficient & Insufficient \\
\hline
\end{tabular}

It is noticed from Table 4 that $9 \%$ of the participants obtained scores between $70 \%-84 \%$ and therefore they have an acceptable level of environmental knowledge. This means that $91 \%$ of the participants do not have a sufficient level of environmental knowledge.

With regard to environmental behavior, the participants were asked to indicate the extent of their environmentally friendly behavior. Means, standard deviation and frequencies are calculated on the scale as a whole and on each item. Table 5 shows the result. 
Table 5: Means, standard deviations, percentage and frequencies of participants scores on each item of the scale and on the scale as a whole

\begin{tabular}{|c|c|c|c|c|c|c|c|c|}
\hline No. & Statement & $\begin{array}{c}\text { Always } \\
\%\end{array}$ & $\begin{array}{c}\text { Often } \\
\%\end{array}$ & $\begin{array}{c}\text { Sometimes } \\
\%\end{array}$ & $\begin{array}{c}\text { Never } \\
\%\end{array}$ & Mean & $\begin{array}{l}\text { St. } \\
\text { dev. }\end{array}$ & $\%$ \\
\hline 1 & $\begin{array}{l}\text { I always send environmental } \\
\text { reports to those in charge }\end{array}$ & 1.8 & 5.4 & 30.4 & 62.5 & 1.46 & 0.68 & 37 \\
\hline 2 & I reuse paper as scrap paper & 19.6 & 21.4 & 43.8 & 15.2 & 2.46 & 0.98 & 62 \\
\hline 3 & $\begin{array}{l}\text { I buy environmentally } \\
\text { friendly products }\end{array}$ & 16.1 & 37.5 & 39.4 & 7.1 & 2.63 & 0.84 & 66 \\
\hline 4 & $\begin{array}{l}\text { I send messages to the media } \\
\text { about environmental issues }\end{array}$ & 2.7 & 5.4 & 25.0 & 67.0 & 1.44 & 0.72 & 36 \\
\hline 5 & $\begin{array}{l}\text { I buy environmentally } \\
\text { friendly products even if they } \\
\text { are more expensive }\end{array}$ & 7.1 & 29.56 & 42.9 & 20.5 & 2.23 & 0.86 & 56 \\
\hline 6 & $\begin{array}{l}\text { I participate in campaigns to } \\
\text { clean public places such as } \\
\text { parks and beaches }\end{array}$ & 16.1 & 19.6 & 33.0 & 31.3 & 2.21 & 1.06 & 55 \\
\hline 7 & $\begin{array}{l}\text { I turn off the light when I } \\
\text { leave a room }\end{array}$ & 76.8 & 14.3 & 8.0 & 0.9 & 3.67 & 0.66 & 92 \\
\hline 8 & $\begin{array}{l}\text { I use water economically, } \\
\text { following the prophet's } \\
\text { saying, "Economize even if } \\
\text { you are next to a river" }\end{array}$ & 65.2 & 22.3 & 11.3 & 0.9 & 3.52 & 0.74 & 88 \\
\hline 9 & $\begin{array}{l}\text { Warn people that throw } \\
\text { garbage in public places }\end{array}$ & 51.8 & 32.1 & 15.2 & 0.9 & 3.35 & 0.77 & 84 \\
\hline 10 & $\begin{array}{l}\text { I collect garbage that others } \\
\text { throw in public places and } \\
\text { place it in disposal bins }\end{array}$ & 27.8 & 42.9 & 23.2 & 6.3 & 2.92 & 0.87 & 73 \\
\hline 11 & $\begin{array}{l}\text { I collect used batteries and } \\
\text { place them in the designated } \\
\text { places, not in garbage in bins }\end{array}$ & 8.9 & 17.9 & 38.4 & 34.8 & 2.01 & 0.94 & 50 \\
\hline 12 & $\begin{array}{l}\text { I turn off the } \mathrm{AC} \text { when I leave } \\
\text { a room }\end{array}$ & 75.9 & 9.8 & 10.7 & 3.6 & 3.58 & 0.82 & 90 \\
\hline 13 & $\begin{array}{l}\text { I pay attention to birds } \\
\text { singing, flowers blooming, } \\
\text { when I am in nature }\end{array}$ & 75.0 & 13.4 & 11.6 & 0 & 3.63 & 0.68 & 91 \\
\hline 14 & $\begin{array}{l}\text { I always participate in } \\
\text { campaigns to prevent } \\
\text { environmental damage }\end{array}$ & 3.6 & 20.5 & 33.0 & 42.9 & 1.85 & 0.87 & 46 \\
\hline 15 & $\begin{array}{l}\text { I follow programs that focus } \\
\text { on national activities which } \\
\text { focus on the environment }\end{array}$ & 18.8 & 30.4 & 37.5 & 13.4 & 2.54 & 0.95 & 64 \\
\hline 16 & $\begin{array}{l}\text { I follow articles in } \\
\text { environmental journals }\end{array}$ & 10.7 & 32.1 & 37.5 & 19.6 & 2.34 & 0.92 & 59 \\
\hline 17 & $\begin{array}{l}\text { I watch programs on TV or } \\
\text { online concerned with the } \\
\text { environment }\end{array}$ & 20.5 & 35.7 & 37.5 & 6.3 & 2.71 & 0.87 & 68 \\
\hline 18 & $\begin{array}{l}\text { I follow programs that give } \\
\text { information about recycling } \\
\text { and reusing materials }\end{array}$ & 19.6 & 33.9 & 39.3 & 7.1 & 2.66 & 0.88 & 67 \\
\hline 19 & $\begin{array}{l}\text { I use public transport instead } \\
\text { of private cars or taxis most of }\end{array}$ & 9.8 & 21.4 & 35.7 & 33.0 & 2.0 & 0.97 & 53 \\
\hline
\end{tabular}




\begin{tabular}{|r|l|c|c|c|c|c|c|c|}
\hline & the time & & & & & & & \\
\hline 20 & $\begin{array}{l}\text { I prefer paying bills online to } \\
\text { use less paper }\end{array}$ & 25.0 & 25.9 & 19.6 & 29.5 & 2.46 & 1.16 & 62 \\
\hline 21 & $\begin{array}{l}\text { I go on a trip either walking } \\
\text { or riding a bus to enjoy nature }\end{array}$ & 32.1 & 29.5 & 29.5 & 8.9 & 2.85 & 0.98 & 71 \\
\hline & Scale as a whole & 27.85 & 23.85 & 28.70 & 19.60 & 2.60 & 0.42 & 65 \\
\hline
\end{tabular}

The previous table shows that the means of environmental behavior scale range from 1.44-3.67. The mean on the scale as a whole is $2.6 / 4$ with a percentage of $65 \%$. This indicates that participants' activities related to environmental behavior are intermediate and less than the acceptable level.

From evaluating the responses of the participants on the environmental behavior scale and calculating the frequency of responses, whether practicing environmental behavior always, often, sometimes, or never, the results indicate that the participants do not practice such behaviors, even only sometimes, particularly in the following areas: sending reports to authorities about environmental problems, sending letters to various media, buying products that are more expensive to protect the environment, participating in campaigns to prevent environmental damage, collecting signatures or writing letters to those in charge, using public transport instead of private cars, or disposing of batteries in allocated places. In these cases, the means range from 1.44-2.23 out of 4 . The results show that participants practice some environmentally friendly behavior in a consistent manner or most of the time especially in areas such as conserving energy and water or disposing of garbage in designated areas.

To answer the second question which is a concern with the relationships between dimensions of environmental literacy (knowledge, behavior, and attitudes)? Pearson correlation coefficients were calculated between knowledge, attitudes, and behavior. Table 6 shows these results.

Table 6: correlation coefficients between three dimensions of environmental literacy

\begin{tabular}{|l|c|c|c|}
\hline $\begin{array}{l}\text { Pearson correlation } \\
\text { coefficient }\end{array}$ & $\begin{array}{c}\text { Environmental } \\
\text { knowledge }\end{array}$ & $\begin{array}{c}\text { Environmental } \\
\text { attitudes }\end{array}$ & $\begin{array}{c}\text { Environmental } \\
\text { behavior }\end{array}$ \\
\hline $\begin{array}{l}\text { Environmental } \\
\text { knowledge }\end{array}$ & 1 & 0.135 & -0.102 \\
\hline $\begin{array}{l}\text { Environmental } \\
\text { attitudes }\end{array}$ & 0.135 & 1 & ${ }^{*} 0.437$ \\
\hline $\begin{array}{l}\text { Environmental } \\
\text { behaviour }\end{array}$ & -0.102 & ${ }^{*} 0.437$ & 1 \\
\hline
\end{tabular}

Table 6 shows that there is a statistically significant correlation at $a=0.01$ between environmental attitudes and behavior reached (0.437), a weak and not significant correlation between knowledge and attitudes, and a weak and negative correlation between knowledge and environmental behavior.

To answer Question Three about the effect of academic year level on the level of environmental literacy among pre-service teachers, means, standard deviations and percentage of students' scores were calculated. Table 7 shows the results. 
Table 7: Means and standard deviations of students' scores on the scale of environmental literacy according to academic level

\begin{tabular}{|l|l|l|l|l|l|l|}
\hline $\begin{array}{l}\text { Environmental Literacy } \\
\text { Scale/sub-dimension }\end{array}$ & & $\begin{array}{c}\text { 1st year } \\
\mathrm{N}=22\end{array}$ & $\begin{array}{c}2^{\text {nd }} \text { year } \\
\mathrm{N}=47\end{array}$ & $\begin{array}{c}\text { 3rd }^{\text {year }} \\
\mathrm{N}-32\end{array}$ & $\begin{array}{c}4^{\text {th }} \text { year } \\
\mathrm{N}=11\end{array}$ & $\begin{array}{c}\text { Total } \\
\mathrm{N}=112\end{array}$ \\
\hline Attitudes & Mean & 3.78 & 3.73 & 3.96 & 4.02 & 3.84 \\
& St. Dev. & 0.31 & 0.30 & 0.34 & 0.36 & 0.33 \\
\hline Behaviour & Mean & 2.50 & 2.59 & 2.65 & 2.69 & 2.60 \\
& St. Dev. & 0.50 & 0.44 & 0.36 & 0.37 & 0.42 \\
\hline Knowledge & Mean & 51.32 & 47.83 & 51.00 & 55.45 & 50.17 \\
& St. Dev. & 18.98 & 14.28 & 13.79 & 15.70 & 15.23 \\
\hline
\end{tabular}

Table 7 shows that the students' means in the area of environmental attitudes were very close to each other among 1st and 2nd-year students (3.78 and 3.73), but increased with students of the 3rd and 4th years (3.96 and 4.02), which indicates that attitudes become more positive as student's advance in their academic level. As for environmental knowledge, it is noticed that the mean of 2nd-year students is $47.83 \%$, followed by mean of 3rd-year students at $51 \%$ and by first-year students at $51.32 \%$. The mean of $55.45 \%$ for 4 th-year students was the highest. Also, the results indicated that the means of students on the environmental behavior scale increased gradually as the academic level rose. In order to find out if there were any statistically significant differences between student's means on the environmental literacy scale according to the academic level, ANOVA test was used. Table 8 shows these results.

Table 8. ANOVA test results of the environmental literacy scale related to attitudes, knowledge, and behavior in relation to academic level

\begin{tabular}{|l|l|l|c|c|c|c|}
\hline & & $\begin{array}{c}\text { Sum of S } \\
\text { squares }\end{array}$ & $\mathrm{df}$ & $\begin{array}{c}\text { Mean } \\
\text { Square }\end{array}$ & $\mathrm{F}$ & Sig \\
\hline \multirow{2}{*}{ Attitudes } & Between groups & 686.26 & 3 & 228.75 & 4.64 & 0.004 \\
& Within groups & 5329.99 & 108 & 49.35 & & \\
& Total & 6016.25 & 111 & & & \\
\hline \multirow{2}{*}{ Knowledge } & Between groups & 20.01 & 3 & 6.67 & 0.88 & 0.452 \\
& Within groups & 815.85 & 108 & 7.55 & & \\
& Total & 835.86 & 111 & & & \\
\hline \multirow{2}{*}{ Behavior } & Between groups & 167.58 & 3 & 55.86 & 0.70 & 0.554 \\
& Within groups & 8613.85 & 108 & 79.76 & & \\
& Total & 8781.43 & 111 & & & \\
\hline
\end{tabular}

It is shown in Table 8 that there are statistical differences at $\mathrm{a}=0.05$ in environmental attitudes according to academic levels which were favorable to 4th-year students, while it is noticed that there were no differences at $\mathrm{a}=0.01$ in knowledge and behavior that can be attributed to the academic year.

To answer Question 4 about the main sources that students rely on to obtain environmental knowledge, frequencies and percentage of sample responses were calculated. Table 9 shows the results. 
Table 9: Sources to obtain environmental knowledge with frequencies and percentages arranged in descending order

\begin{tabular}{|c|l|c|c|}
\hline & \multicolumn{1}{|c|}{ Source } & frequencies & Percentage $\%$ \\
\hline 1 & Internet & 91 & $81 \%$ \\
\hline 2 & Television & 66 & $59 \%$ \\
\hline 3 & Lectures & 44 & $39 \%$ \\
\hline 4 & Family and friends & 43 & $38 \%$ \\
\hline 5 & Books & 20 & $18 \%$ \\
\hline 6 & Radio & 14 & $13 \%$ \\
\hline 7 & Other sources & 10 & $9 \%$ \\
\hline 8 & Scientific journals & 6 & $6 \%$ \\
\hline 9 & Newspapers & 5 & $5 \%$ \\
\hline
\end{tabular}

Table 9 shows that the most common source was the Internet at $81 \%$, followed by TV at $59 \%$, lectures at $39 \%$, books at $18 \%$, and scientific journals at $6 \%$.

\section{Discussion}

The results of the study show that the mean of students' scores on the scale of environmental attitudes was $3.84 / 5$, or $77 \%$, indicating that environmental attitudes were positive and above the minimum acceptable level. The study also showed that participants' average in environmental knowledge was $50.7 \%$ and environmental behavior was $2.6 / 4$ or $65 \%$, indicating that the results regarding environmental knowledge and behavior were less than the acceptable level according to the standard of $70 \%$.

These results are in agreement with many studies conducted in other countries (Lloyd-Strovas, Moseley and Arsuffi, 2018; Amirshokoohi, 2010; DeChano, 2006; Jasim, (2001), and indicate that pre-service classroom teachers at the University of Petra do not possess an acceptable level of environmental literacy in the dimensions of knowledge and behavior, even though they have graduated from high school and obtained high school diplomas that qualify them for university. In conclusion from their weakness in environmental knowledge that most of the students in the teacher training program at the university are holders of high school diplomas in the arts stream who therefore did not study specialized environmental courses in the 11th and 12th grades. This has reflected negatively on their level of environmental knowledge which in turn has limited their environmental literacy. It also seems that high school science courses and textbooks do not include sufficient knowledge about environmental issues, or that teachers of environmental subjects fail to use effective methods. This assumption requires a reconsideration of the context of high school science texts and the way they are taught. Moreover, teaching methods must be developed in constructive ways that include hands-on activities.

In addition, formal sources of environmental knowledge for many pre-service teachers are limited to university courses offered as electives rather than as separate required courses that deal specifically with the environment. Thus, environmental issues may be included only indirectly in science courses that do not focus on teaching activities based on inquiry related to protecting the 
environment. Also the Jordanian Ministry of Higher Education specifies the cognitive domains for the class teacher program and allocates 6 to 9 credited hours to science courses which include environmental sciences. Due to the limited time, environmental topics cannot be fully covered.

The low level of environmental knowledge can also be explained by the failure of various formal and informal institutions and the weak role that the Jordanian media plays in disseminating appropriate information about local and global environmental issues. A study conducted by Musa (2003) showed that there is a lack of coverage of environmental problems in official newspapers. Local media devote insufficient time to environmental issues and limit coverage to pollution and water scarcity while neglecting other local or global environmental issues.

The low level of environmental knowledge seems to be consistent with many previous studies. DeChano (2006) noted that most environmental literacy research showed that there is a low level of literacy among students which is not limited to a specific country but is generally true internationally.

The results of this study disclosed that environmental attitudes were acceptable at a percentage of $77 \%$. This is in agreement with various other studies (AlDajeh, 2012; Batayneh, 2012; Liu et al., 2015; Saribas, 2015; Lloyd-Strovas, Moseley and Arsuffi, 2018). This may be due to the fact that many compulsory courses at university focus on developing affective aspects such as values and attitudes. These courses have a positive influence on students' attitudes toward the environment as well as on developing environmental values which subsequently promote working for the environment and practicing environmental behavior, helping students face environmental changes and make appropriate decisions. The absence of even stronger environmental attitudes can be attributed to the unhelpfully low level of environmental knowledge. The conclusion is that students need to strengthen their knowledge of local and global environmental issues which will aid them in forming more positive attitudes toward the environment.

As indicated in this study, the environmental behavior of the respondents was medium at a percentage of $65 \%$. This result can be explained by the fact that students displayed a limited knowledge, mainly theoretical, of environmental issues in addition to ignorance of the methods or legislation needed to protect the environment by officials, while through their personal practices they need to learn to act as role models for future students. Undoubtedly, the mediocre environmental literacy of classroom teachers does not qualify them to educate their students or help them to face environmental problems and reduce their dangers, all of which reflect negatively on their competence as future educators.

Based on the academic year, there were statistically significant differences in the attitudes of student teachers towards the environment which was to the benefit of 4th-year students. These results are consistent with many studies (Öztürk, Tüzün, and Teksöz, 201; O'Brien, 2007). While results showed that there were no statistically significant differences in cognitive and behavioral aspects of environmental literacy due to the level of the academic year, this may mean that while teacher training programs contribute to developing positive attitudes 
towards the environment, they do not contribute to increase environmental knowledge or changes in behavior. Thus, it seems that students rely on other sources for environmental knowledge, even though these sources often lack accuracy, comprehensiveness, or depth.

The correlation coefficient between knowledge and attitudes was 0.437. This finding is consistent with the results of several studies that indicated a positive correlation such as Arcury (1990), Al-Dajeh (2012), Tuncer, et al., (2009), but differ from that of DeChano (2006) who concluded that there is no significant correlation. The low correlation between environmental knowledge and attitudes can be ascribed to a mediocre environmental knowledge, the limits of the questionnaire, or the small sample size, and the disagreement among studies regarding the correlation between knowledge and attitudes can be attributed to not using the same tools in all of the studies.

The most reliable sources for obtaining environmental knowledge were the Internet $(81 \%)$, television (59\%), followed by formal lectures $(39 \%)$, and friends and family (38\%). The recurrent use of the Internet may be attributed to its ease of access to many sites and the development of information and communication technologies. There is no doubt that some of these sources, especially the Internet and television, contain considerable knowledge and information, some of which is accurate and objective but otherwise may be wrong or misleading, producing unrelated, false, or insufficient knowledge or the formation of misconception among prospective teacher about environmental issues. This result is in agreement with various other studies such as(Al-Dajeh, 2012; Ocal, Kisoglu, Alasand Gurbuz, 2011;) which indicated that the main source of information is the Internet and TV and that pre-service teachers do not depend on reliable sources such as formal lectures. It is apparent that students resort to many sources to obtain environmental knowledge, whether formal sources, such as schools, or informal sources, such as the media, friends, and family (Coyle, 2005)

\section{Conclusion}

The study aimed to assess the level of environmental literacy among Prospective teachers by considering its three dimensions (knowledge, attitudes, and behavior), the relation between these dimensions, and the impact of the academic year level on environmental literacy. It also intends to explore the sources that students draw on to develop environmental literacy and the most important local and global environmental problems from their point of view. The results of this study showed that prospective teachers have low levels of environmental literacy, knowledge of the environmental challenges facing Jordan, indicating that the university teacher preparation program at the basic level does not provide students with sufficient environmental literacy. Further effort is necessary to introduce concepts of environmental education in teacher training programs and to offer compulsory courses that cover global, regional, and local environmental problems as well as how to preserve and sustain environmental resources. The goal is to increase environmental knowledge and develop positive attitudes that will influence behavior and teach students to 
become environmentally friendly. Environmental clubs will encourage students to engage in environmental activities, increase their knowledge of environmental issues, and equip them to deal with the environmental challenges facing Jordan.

\section{Recommendations}

Based on the results of this study, many recommendations that may contribute to raising the level of environmental literacy as following:

- Include environmental concepts in courses taught to pre-service teachers

- Introduce a compulsory course in environmental education that focuses on developing environmental attitudes and knowledge and encourages students to practice environmental behavior

- Conduct research to explore the level of environmental literacy and attitudes towards the environment among university students in different disciplines

- Promote activities to increase environmental literacy such as the establishment of environmental clubs

\section{References}

Al-Dajeh, H. (2012). Assessing environmental literacy of pre-vocational education teachers in Jordan. College Student Journal, 46(3), 492-507.

Al-Khawaldeh, A. B. (2000). The level of environmental literacy of science teachers in Jerash governorate and its relation to gender, experience, qualifications, and field of specialization. Unpublished MA thesis, Yarmouk University.

Al-Omari, A., \& Al-Khawaldeh, S. A. (2013). Environmental literacy among students of the faculty of education at Yarmouk university. Journal of Educational and $\begin{array}{llll}\text { Psychological Studies } & \text { [JEPS], } & 7(2), & 133-150 .\end{array}$ https://doi.org/10.24200/jeps.vol7iss2pp133-150

Amirshokoohi, A. (2010). Elementary pre-Service teachers. environmental literacy and views toward science, technology, and society (STS) issues. Science Educator, 19(1), 56-63.

Arcury, T. A. (1990). Environmental attitude and environmental knowledge. Human organization, 300-304. https://doi.org/10.17730/humo.49.4.y6135676n433r880

Arik, S., \& Yilmaz, M. (2017). Prospective science teachers' attitude toward the environmental problems and their metaphorical perceptions about "environmental pollution". Kastamonu Ĕgitim Dergisi, 25(3), 1147-1164.

Atabek-Yiğit, E., Köklükaya, N., Yavuz, M., \& Demirhan, E. (2014). Development and validation of environmental literacy scale for adults (ELSA). Journal of Baltic Science Education, 13(3), 425-435.

Ayash, A., \& Abu Snaneh, O. (2013). The Efficacy of a training program based on the environmental education in developing environmental literacy and positive attitudes towards the environment for faculty of education, science, and arts (FESA). Al-Balqa Journal for Research and Studies, 16(2) UNRWA, Jordan.

Batayneh, M. Q. (2012). The level of environmental literacy among environmental institution leaders and Jordanian university students in light of contemporary environmental thought. Ph.D. dissertation, Yarmouk University.

Cheng, I. N. Y., \& So, W. W. M. (2015). Teachers' environmental literacy and teachingstories of three Hong Kong primary school teachers. International Research in 
Geographical and Environmental Education, 24(1), 58-79. https:/ / doi.org/10.1080/10382046.2014.967111

Coyle, K. (2005). Environmental literacy in America: What ten years of NEETF / Roper research and related studies say about environmental literacy in the U.S. National Environmental Education Training Foundation.

Dada, D. O., Eames, C., \& Calder, N. (2017). Impact of environmental education on beginning preservice teachers' environmental literacy. Australian Journal of Environmental Education, 33(3), 201-222. https://doi.org/10.1017/aee.2017.27

DeChano, L. M. (2006). A multi-country examination of the relationship between environmental knowledge and attitudes. International Research in Geographical and Environmental Education, 15(1). https://doi.org/10.2167/irgee/184.0

Saribas, D., \& Gonca Akdemir, Z. (2019). Using an innovative tool in science education: examining pre-service elementary teachers' evaluation levels on the topic of wetlands. International Journal of Science Education,41(1), 123-138. https://doi.org/10.1080/09500693.2018.1536302

Derman, A., \& Hacıeminoğlu, E. (2017). Sürdürülebilir gelişme için eğitim bağlamında sınıf öğretmenlerinin çevre okuryazarlığı düzeyleri. Ondokuz Mayıs Üniversitesi Eğitim Fakültesi Dergisi, 36(2), 81-103.

Disinger, J. F. (2001). K-12 education and the environment: perspectives, expectations, and practice. The Journal of Environmental Education, 33(1), 4-11. https://doi.org/10.1080/00958960109600795

Erdoğan, M. (2009). Fifth grade students' environmental literacy and the factors affecting students' environmentally responsible behaviors. Unpublished Ph.D. dissertation, Middle East Technical University, Turkey.

Erdoğan, M., Kostova, Z., \& Marcinkowski, T. (2009). Components of Environmental Literacy in Elementary Science Education Curriculum in Bulgaria and Turkey. Eurasia Journal of Mathematics, Science $\mathcal{E}$ Technology Education, 5(1). https://doi.org/10.12973/ejmste/75253

Fielding, K. S., \& Head, B. W. (2012). Determinants of young Australians' environmental actions: The role of responsibility attributions, locus of control, knowledge, and attitudes. Environmental Education Research, 18(2), 171-186. https://doi.org/10.1080/13504622.2011.592936

Gillett, M. (1977). The tbilisi declaration. McGill Journal of Education/Revue des sciences de léducation de McGill, 12(002).

Jasim, S. (2001). Environmental literacy of teachers of science in the intermediate stage in Kuwait. Journal of Educational \& Psychological Sciences, JEPS, 2(1).

Joseph, C., Obrin Nichol, E., Janggu, T., \& Madi, N. (2013). Environmental literacy and attitudes among Malaysian business educators. International Journal of Sustainability in Higher Education, 14(2), 196-208. https:/ / doi.org/10.1108/14676371311312897

Karatekin, K. (2013). Comparison of Environmental Literacy Levels of Pre-service Teachers. International Journal of Academic Research, 5(2). https:/ / doi.org/10.7813/2075-4124.2013/5-2/B.1

Kaya, V. H., \& Elster, D. (2018). German Students' Environmental Literacy in Science Education Based on PISA Data. Science Education International, 29(2), 75-87.

Khalaf, A. M (2012). The role of specialized media messages in the development of environmental awareness: an applied study of Birzeit University students. MA thesis, Birzeit University.

Liu, S. Y., Yeh, S. C., Liang, S. W., Fang, W. T., \& Tsai, H. M. (2015). A national investigation of teachers' environmental literacy as a reference for promoting environmental education in Taiwan. The Journal of Environmental Education, 46(2), 114-132. https:/ / doi.org/10.1080/00958964.2014.999742 
Lloyd-Strovas, J., Moseley, C., \& Arsuffi, T. (2018). Environmental literacy of undergraduate college students: Development of the environmental literacy instrument (ELI). School Science and Mathematics, 118(3-4), 84-92. https://doi.org/10.1111/ssm.12266

Malandrakis, G., Boyes, E., \& Stanisstreet, M. (2011). Global warming: Greek students' belief in the usefulness of pro-environmental actions and their intention to take action. International Journal of Environmental Studies, 68(6), 947-963. https://doi.org/10.1080/00207233.2011.590720

Morrone, M., Mancl, K., \& Carr, K. (2001). Development of a metric to test group differences in ecological knowledge as one component of environmental literacy. The Journal of Environmental Education, 32(4), 33-42. https://doi.org/10.1080/00958960109598661

Musa, M. A. (2003). Environmental literacy and the mass media: an analytical study. $M A$ thesis, University of Jordan.

O'Brien, S. R. M. (2007). "Indications of environmental literacy: using a new survey instrument to measure awareness, knowledge, and attitudes of university-aged students". Retrospective Theses and Dissertations. 15055. Retrieved from: lib.dr.iastate.edu/rtd/15055.

Ocal, A., Kisoglu, M., Alas, A., \& Gurbuz, H. (2011). Turkish prospective teachers' understanding and misunderstanding of global warming. International Research in Geographical and Environmental Education, 20(3), 215-226. https://doi.org/10.1080/10382046.2011.588504

O'Neill, K. (2007). From Stockholm to Johannesburg and beyond: the evolving metaregime for global environmental governance. In the Amsterdam conference on the human dimensions of global environmental change ( $p p$. 24-26).

Özden, M. (2008). Environmental awareness and attitudes of student teachers: An empirical research. International Research in Geographical and Environmental Education, 17(1), 40-55. https://doi.org/10.2167/irgee227.0

Öztürk, G., Tüzün, Ö. Y., \& Teksöz, G. (2013). Exploring environmental literacy through demographic variables. Ilkogretim Online, 12(4).

Roth, C. E. (1992). Environmental literacy: Its roots, evolution, and directions in the 1990s.

Saribas, D., Kucuk, Z. D., \& Ertepinar, H. (2017). Implementation of an environmental education course to improve pre-service elementary teachers' environmental literacy and self-efficacy beliefs. International Research in Geographical and Environmental Education, 26(4), 311-326. https://doi.org/10.1080/10382046.2016.1262512

Saribas, D. (2015). Investigating the Relationship between Pre-Service Teachers' Scientific Literacy, Environmental Literacy and Life-Long Learning Tendency. Science Education International, 26(1), 80-100.

Tuncer, G., Tekkaya, C., Sungur, S., Cakiroglu, J., Ertepinar, H., \& Kaplowitz, M. (2009). Assessing pre-service teachers' environmental literacy in Turkey as a means to develop teacher education programs. International Journal of Educational Development, 29(4), 426-436. https://doi.org/10.1016/j.ijedudev.2008.10.003

UNEP, 1972. Declaration of the United Nations Conference on the Human Environment.

Weber, J. M., Hair Jr., J. F., \& Fowler, C. R. (2000). Developing a measure of perceived environmental risk. The Journal of Environmental Education, 32(1), 28-35. https://doi.org/10.1080/00958960009598669 